\title{
Interrogating Strategies of Justice and Racial Politics: A Post- colonial Reading of Abir Mukherjee's A Rising Man
}

\author{
Febin Vijay and Priyanka Tripathi ${ }^{2}$ \\ IJunior Research Fellow (PhD), Department of Humanities and Social Sciences, Indian \\ Institute of Technology Patna. febinvijay777@gmail.com \\ ${ }^{2}$ Associate Professor of English, Department of Humanities and Social Sciences, Indian \\ Institute of Technology Patna. ORCID: 00oo-0oo2-9522-3391.
}

\begin{abstract}
The present article begins with a brief historical account of the exclusionary politics of Western crime fiction, with most of the works representing the East as 'exotic other' while assuming the subject position themselves. A post-colonial analysis of Abir Mukherjee's A Rising Man (2016) is conducted to study how the novel deals with questions of justice and racial politics, and further encompasses a brief inquiry into it can be positioned as an anti-colonial text which advocates a move towards decolonization. The text can be seen as representing the body of work by writers who give voice to the oppressed within colonial contexts and vehemently refuse the idea of being inferior.
\end{abstract}

Keywords: post-colonial, justice, race, crime, violence.

As the genre of crime fiction expanded beyond its Anglo-American realms and traversed into some of the previously colonized nations, it witnessed a variety of forms in terms of its adaptations. Writers of the genre from these spaces made use of it 'to write back' against the canon; this very act of using a Western genre and renegotiating its constituents into culturally specific themes can be seen as a post-colonial act. A recurring line of thought or ingredient in post-colonial crime fiction is that more often than not, the cases - regardless of whether they are crimes or mere transgressions - are linked to the elements of "colonialism and to neo-colonial corruption, usually provoked or magnified by rampant neoliberalism" (Alonso-Breto, 2016, p. 4).

The critical discourse of post-colonialism explores how various nations, authorities, and people from erstwhile colonies of the world experience and navigate with the issues of power, economy, politics, and culture and also how make ways for their presence with dominant colonial hegemony. The term 'post' in post-colonialism in no way means that the after-effects of colonial rule have elapsed; rather, it signifies the influence that the imperial and colonial histories have in forging a colonial way of looking at things and how European forms of knowledge and authority marginalize the Eastern world. In short, post-colonialism concerns itself with analyzing and addressing power and economic relations, thereby advocating a motion towards egalitarianism. However, when it comes to post-colonial writers using English language as a medium of creative expression, "English is no longer a coloniser's language for it has become a tool of decolonisation" (Sharma et al., 2015, p. 11). Decolonization is the process of exposing and undoing colonialist sovereignty in all its forms. Further, it encompasses breaking the obscure facets of institutional and (c) AesthetixMS 2021. This Open Access article is published under a Creative Commons Attribution Non-Commercial 4.0 International License (http://creativecommons.org/licenses/by-nc/4.o/), which permits non-commercial re-use, distribution, and reproduction in any medium, provided the original work is properly cited. For citation use the DOI. For commercial re-use, please contact editor@rupkatha.com. 
cultural powers that upheld the colonial dominance and that which prevails even after political freedom is attained. It operates as a counter-discourse that gives voice to the indigenous people and helps them discover their misplaced subjectivity (Sharma et al., 2015, p. 11). According to Prasenjit Duara, the term embodies not only the transference of legal jurisdiction but also an undertaking towards "moral justice and political solidarity against imperialism" (Duara, in Gunde 1994).

Post-colonial crime fiction refers to crime novels which examine the crimes of colonialism and neo-colonialism; it includes "the perspectives and values of previously colonized subjects, whilst utilizing a literary aesthetic and epistemology which are modified by a specific postcolonial context" (Naidu, 2018, p. 83). Crime fiction produced in the West has an extensive history of representing Eastern nations as the 'exotic other' while taking up the subject position themselves. This is particularly evident in the representation of violence in some of these works; more often than not, the element of violence is increasingly associated with the Orient. Even when Oriental malefactors are absent within works such as Arthur Conan Doyle's Sherlock Holmes series, "spaces like South America, Africa and India are synecdochically represented through strangely horrific indigenous poisons (or even a poisonous snake), all of which are used in murders within England" (Roy, 2020, p. 121). As stated by Maureen T. Reddy, early works of hard-boiled crime ${ }^{1}$ fiction of the 1920 and 1930 forged a cultural image of the sleuth which presented whiteness, heterosexuality and conventional masculinity as the normative standards of the genre (2003, p. 7). However, over the past couple of decades, several white (most often male) writers have centered their fictional crime narratives on Asian protagonists but more often than not they have fallen into the same Orientalist trap of accentuating numerous stereotypes. Some of these writers and their Asian protagonists include Eliot Pattison and his Beijing Justice Department investigator Shan Tao Yun; John Burdett and his Royal Thai police force detective Sonchai Jitpleecheep; and Colin Cotterill and his French-trained physician Dr. Siri Paiboun (Makhijani, 2017). These contemporary writers of crime fiction have been condemned for representing imported and exoticized perspectives, which lack authenticity, through their writings. In short, their representations of the Asian settings were considered artificial and lacking credibility by some critics. For instance, even though Biggers claimed to have created his protagonist in reaction to anti-Chinese stereotypes that he witnessed in California, his fictional representation speaks otherwise. Chan's character embodies a mixture of stereotypes - he is "a portly and effeminate man who speaks faux-Confucian aphorisms" (Makhijani, 2017). In Charlie Chan: The Untold Story of the Honorable Detective and His Rendezvous with American History (2010), Yunte Huang posits, "Make no mistake: Charlie Chan is an American stereotype of the Chinaman. Anyone who believes that Chan is Chinese would probably also believe that the fortune cookie is a Chinese invention" (p. 19). While deliberating on John Burdett's novels, Laotian American writer Bryan Thao Worra rebukes that Jitpleecheep's mysteries are always set in or adjacent to Thailand's red-light districts and portray "lots of exotic deaths and kinky eroticism" (in Makhijani, 2017).

The notion of the foreign and the post-colonial have long existed in the area of crime and detective fiction, with works set in the colonies having a long and complex history within the British tradition (Morgan, 2020, p.3). Prabhat K. Singh calls attention to the rise of genre fiction in English in India and urges the readers to recognize the significance of genre fiction (2013, p.8). The development of crime fiction in India can be categorized into three stages, and they correspond to the phases in the cultural trajectory of the colonized intellectual as outlined by Frantz Fanon in his seminal work The Wretched of the Earth $(1965$, p. 222). The first stage is one of mimicry where the colonized mimic the colonizer and conforms to the latter's desires. In other words, the colonized attempts to be like the Europeans, assimilating the various constituents that comprise Western 
culture. This is the stage where writers of crime fiction in India wrote fiction that was more or less exact replicas of their Anglo-American varieties. The local fictional detectives like Sharadindu Bandyopadhyay's Byomkesh Bakshi, Asrar Ahmad's (popularly known as Ibn-e-Safi) Ali Imran and Kalpana Swaminathan's more contemporary Lalli were modelled on Sherlock Holmes, Nick Carter and Miss Marple respectively. The second stage is characterized by the colonized revolting against the colonizer. Parallel to this lies the Indian writers' attempt to adapt the genre and make minor changes to it, even though a torrent of Western elements were still retained as part of colonial hangover. The final phase is the one where the colonized finally embrace its culture and contest for emancipation from the colonial regime. They write "a fighting literature, a revolutionary literature and a national literature" (p. 223) in the hopes of discovering their own true identity and subjectivity in the process. This is the phase where writers produced post-colonial metafiction, "a narrative mode that accommodates the self-questioning ambiance of the postmodern and the politicised stance of the post-colonial" (Gamal, 2011, p. 1). According to Gamal, metafiction operates as a postcolonial tool of rewriting and hence recuperating the history of the colonized (p. 1). In the arena of Indian crime fiction, while most of the earlier works tried to emulate Western works without much experimentation or representation, the modern writers have taken up the task of redefining the genre by incorporating the innate 'Indian-ness' into their works. Indian culture is more heterogeneous in comparison to its Western counterpart and this heterogeneity adds to its diversity. This cultural diversity leads to a thematic diversity as well as diversity in terms of characterization, and consequently, the cultural imageries in the Indian detective fiction are more vibrant and dynamic.

One of the significant developments that can be seen when it comes to the arena of Indian crime fiction is the multifarious collection of historical works with colonial or pre-colonial settings. Abir Mukherjee's Sam Wyndham series, Sujata Massey's The Widows of Malabar Hill (2018, also published as A Murder on Malabar Hill), Arjun Raj Gaind's A Very Pukka Murder (2016), and Madhulika Liddle's Muzaffar Jang series are some works that belong to this category. Such hybridization of genres reflects a "postmodern tendency towards rejecting boundaries between (socalled) high and low art forms and blurring, when not altogether dissolving, generic distinctions" (Humann, 2020, p. 57). In crime fiction, genre hybridization opens up novel avenues that turn it into a more appropriate medium for challenging existing social conventions, raising awareness about global issues and critiquing existing socio-political constructs (p. 59).

Abir Mukherjee's debut novel, A Rising Man was first published in 2016 and was shortlisted for both the Crime Writers' Association (CWA) Gold and CWA Historical Daggers (which he eventually won), the Historical Writers' Association Debut Crown in 2017, and the Mystery Writers of America (MWA) Edgar Award for Best Novel in 2017 (Majumdar, 2018). Perhaps what makes his writing stand out from other crime narratives that deal with similar themes is the fact that even though his writing gets political; it turns away from being polemical. The representation of postcolonial elements in the novel is subtle, balanced and does not interfere with the central plot that involves the murder investigation of a British official. According to Shampa Roy, the investigation of crimes in detective novels entailing post-colonial elements is invariably tied to examining the crimes of colonial regimes and what has followed in their wake from the perspectives of previously colonized subjects (2020, p.120). The protagonists of such novels serve as a medium for the transmission of the author's response to colonialism and its aftermath. What makes Mukherjee's writing particularly interesting is the unbiased way in which he can account for the events concerning the colonial rule in India. Born to Indian parents who immigrated from Calcutta and having spent most of his life in West Scotland (currently lives in London), Mukherjee takes up a 
dual identity using which he represents the standpoints of both the nations in a neutral, unprejudiced manner. Mukherjee's fascination with the tartan noir, a popular form of noir in Scotland, is evident in his representation of the binaries of good and evil and social commentary in A Rising Man. In an interview with Samhita Chakraborty, he reveals his fondness for tartan noir and how he has always been captivated by the idea of representing a good man upholding a bad system in which he does not believe (2019). This is exactly what we get to see in the novel under study - both the main characters, Captain Sam Wyndham, former Scotland Yard detective and a World War I veteran working for the Calcutta Police under the British rule, and Sergeant Surendranath Banerjee of the Calcutta Police, represent the same dilemma. The present article entails a post-colonial analysis of Abir Mukherjee's A Rising Man (2016) to study how the novel deals with questions of justice and racial politics, and it further encompasses a brief inquiry into how the novel positions itself as an anti-colonial text and advocates a move towards decolonization. The text can be seen as representing the body of work by writers that give voice to the oppressed within colonial contexts and categorically refuse the idea likening being colonized to being inferior, thereby situating themselves within a body of works with a similar agenda of freeing minds from colonial, Eurocentric ideology.

The novel begins with the corpse of an Englishman being discovered in an alley located within a shady part of Calcutta. Inspector Sam Wyndham, a World War I veteran and a former Scotland Yard detective, is assigned to investigate the case. The year is 1919 and Sam being new to the city means that he has to seek the help of his colleagues - Sergeant Digby and Sergeant Surendranath Banerjee - to navigate the city and better understand its workings. Digby is an arrogant Englishman who embodies all the abominable attitudes of imperial authority and holds a personal grudge against Sam for landing the job he believes should be his own. Surendranath - or "Surrender-Not" Banerjee as he is often referred to by the Brits as they find the former too hard to pronounce - is an Oxford-educated Indian from a prosperous family. There is a note written in Bengali stuffed into the corpse's mouth which translates to: "No more warnings. English blood will run in the streets. Quit India!" (Mukherjee, p. 6). The victim is soon identified as Alexander MacAulay, an aide and fixer to the Lieutenant-Governor, one of the many officers working under the colonial government. Since MacAulay holds a prominent position in the empire, his murder is suspected of having a political angle to it and the initial speculation point towards an attack carried out by 'terrorists' seeking independence. This incident is what drives the plot of the novel and the remaining portion of the text deals with the investigation of MacAulay's murder.

Throughout the novel, Mukherjee examines the compelling question of the moral legitimacy of the colonial regime. While making enquiries about MacAulay's murder, Wyndham and Banerjee come across a sign etched on the gates of The Bengal Club that reads, "No dogs or Indians beyond the point" (p. 82). Seeing Wyndham's discomfort, Banerjee says, "Don't worry, sir. We Indians know our place. Besides, the British have achieved certain things in a hundred and fifty years that our civilisation didn't in over four thousand [...] We never managed to teach the dogs to read" (p. 82). Here, Abir Mukherjee makes use of Banerjee's character to condemn the colonial administration which restricted Indians from entering various spaces within their own country.

Charles J. Rzepa and Lee Horsley, in their introduction to A Companion to Crime Fiction (2010) states that "detective fiction has remained a resilient and versatile genre because [...] it represents the investigation of individual crimes but can also work to expose the failures, traumas and brutalities of political and social life" (p. 1). Ed Christian too reiterates this idea when he posits that "as a genre, detective fiction often moves from the interrogation of suspects to the interrogation of society" (2010, p. 284). In post-colonial crime fiction, the detective fights crime on 
two levels simultaneously - besides solving the immediate, obvious crime, they also deal with the 'larger' crime of colonialism and its aftereffects on the colonies. These writings question the very definition of 'crime' and emend it to incorporate the "violations and abuses of colonialism, slavery, [and] genocide [...]" (Naidu, 2020, p. 114). In Mukherjee's novel, the immediate crime is MacAulay's murder and the train robbery which is solved at the end of the novel; however, the greater crime of paramount importance brought about by the colonial hegemonic system remains unsolved. These are crimes that cannot be solved within a short period and require constant negotiation over several years. The representation of justice in the novel is obscure and by depicting this perverted form of justice, the author aims to highlight the oppression faced by the colonized throughout history. From the very moment the corpse is discovered, suspicion arises against the native 'terrorists', their struggle for freedom being the crime. As the scene of the crime is near Mrs. Bose's brothel, Wyndham and his colleagues decide to question her and she responds, "[...] people are killed in this part of the city every day [...] Normally, the unfortunate wretch is simply carted off to the morgue and that's the end of it. Why all the fuss this time?" (Mukherjee, p. 11). The difference this time lied in the fact that it was an Englishman who had been murdered and not a native. This represents the level of disparity when it comes to justice; in their own land, Indians were subjected to a form of justice which was completely different from the one applicable for the English folk. As Surendranath asks later in the novel, "Does British justice mean justice only for the British?" (p. 288).

Mukherjee's narrative also makes frequent references to various other injustices such as the Rowlett Act and laws against people organizing peaceful gatherings. The Rowlett Act (or The Anarchical and Revolutionary Act of 1919) was passed by the Imperial Legislative Council in 1919. According to this act, the government could arrest and imprison citizens without a formal trial; it aimed to suppress and deprive revolutionary groups of their right to individual expression and liberty. Similarly, most gatherings involving any mention of freedom struggle were labelled seditious and the organizers, as well as the participants, were jailed. When Benoy Sen, an Indian revolutionary was arrested on suspicions of murdering MacAulay, Inspector Wyndham asks him, "Do you know why you've been arrested" to which Sen responds, "Do you need a reason?" (p. 204). When questioned about his role in organizing a gathering in favor of the need for independence, he responds,

"Under this law, Indians are banned from meeting in their own homes to discuss their desire for freedom in their own country. It was passed by Englishmen without the consent of the Indians to whom it applies. Wouldn't you agree that such a law is unjust? Or do you believe that an Indian, unlike a European, should not have the right to determine his own destiny?" (p. 206).

Through the above-mentioned instances, Mukherjee uses Sen's character to represent the extent to which Indians were oppressed by the British; a myriad of laws was imposed to limit any form of dissent against the British rule. While elaborating on his concept of Justice, Plato refers to Thrasymachus, an ancient Greek sophist who first articulated that "Justice is in the interest of the stronger" or "might is right" (Plato \& Bloom, 1968, p. 15). This is exactly what we get to see in the novel under study; the guilt of an Indian is often at the predisposition of the ruling English, whether the charges are true or not is irrelevant. When Sen is accused of the charges, Inspector Digby says, "The man is guilty. Whether he admits it or not is irrelevant [...] He would be pronounced guilty and hanged" (Mukherjee, p. 217). 
In several parts of the novel, the natives are represented as violent and untrustworthy while the English are depicted as requiring protection from these "nefarious natives" (p. 139). This association of violence with natives runs parallel to the linking of violence with the East in Western crime fiction. The irony lies in the fact that when the English Brigadier-General Dyer shot down a peaceful, unarmed crowd without warning or a chance to disperse in Jallianwala Bagh in Amritsar, he is hailed and glorified as a hero and the Lieutenant Governor of Punjab credits him with "averting an armed insurrection" (p. 283). Throughout the narrative, locals are suspected of murdering MacAulay and it's only towards the end that it is revealed that the crime is committed by the Lieutenant Governor himself through Inspector Digby, yet another Englishman. The ending can be seen as a backlash against the British overlooking their own countrymen as potential perpetrators of violence. Even after the perpetrators are identified, no serious action is taken against them. Inspector Digby dies in the end but is given a posthumous promotion for the part he played in the investigation. Similarly, Wyndham and the Commissioner are helpless when it comes to holding the Lieutenant Governor culprit as his power is beyond their reach. They decide to make use of the situation as leverage and prevent the L-G from interfering with the police cases in the future. In a setup where Indians are imprisoned and hanged for the smallest of crimes, this resolution brings forth the discrepancy in terms of justice in colonial India.

Through the course of the narrative, Mukherjee sheds light on the racial politics within colonial India. Statements such as "In India, it seemed, even the forces of the law and order were subordinate to the hard fact of race" (p. 77) and "[w] hile the colour of a man's skin should have no bearing on the importance of the case, the reality was that it generally did [...]" (p. 72) demonstrate the extent to which race was a deciding factor in the kind of justice received by the individual. The plight of Anglo-Indians is way worse; they are ousted by both the Indians and the English. As a result, they fail to attain a sense of belonging to either of the categories.

Postcolonial Postmortems: Crime Fiction from a Transcultural Perspective (2006) by Christine Matzke and Susanne Muehleisen presents how post-colonial crime fiction has expanded and reworked the genre of crime fiction to discuss issues related to community, race, gender and various other sociopolitical issues (Matzke and Muehleisen, in Naidu 2020, p. 113). The result is a newly emerging postcolonial crime fiction which is characterized by hybridity, especially among the detective figures, making them more effective in their respective settings (p. 113). These detectives combine "western police methods and indigenous cultural knowledge" (Christian, 2001, p. 13) throughout their investigation. This trend is evident in Mukherjee's novel too; as Captain Wyndham is new to the city of Calcutta, he soon realizes the importance of indigenous cultural knowledge during the process of investigation and that he cannot sustain in this new terrain with his mere Western policing methods alone.

One of the several ways in which Indian writers of crime fiction writing in the English language strive towards decolonization is through their very use of language itself. According to Salman Rushdie, "[t]he language like so much else in the colonies, needs to be decolonized, to be remade in other images, if those of us who use it from positions outside Anglo-Saxon culture are to be more than artistic Uncle Toms" (in Schröttner 2009, p. 295). The writers of crime fiction in India often use a hybrid form of English intermingled with words from their native, regional languages (Hindi and Bengali being the most popular choices). This 'chutnification'z of the English language with words from regional languages like Hindi and reflect India's hybrid culture. For instance, Abir Mukherjee's A Rising Man makes use of several Indian words like wallah ${ }^{3}$, sahib ${ }^{4}$, gullee ${ }^{5}$, lathi $^{6}$, and $a_{\text {schee }}{ }^{7}$. The entire narrative is coalesced with such words, thus serving to illustrate how linguistic aspects function in the process of literary decolonization. Ngũgi wa Thiong'o is of the view that 
"language carries culture and culture carries, particularly through orature and literature, the entire body of values by which we come to perceive ourselves and our place in the world" (1986, p. 13). As a result, a difference in the use of language can be seen as a positive step towards freeing our indigenous culture from indirect colonial domination. A post-colonial reading of Abir Mukherjee's A Rising Man (2016) exposes the ways in which the crime genre is used to address issues of social concern such as injustice and racial prejudice. By constantly engaging in a dialogue on colonialism and its implications on the Indian society, such texts propagate a move towards liberating our psyche from imperialist ideology and thereby recover our true identities.

Acknowledgement: This work was supported by the 'University Grants Commission (190510080572/NET JRF-JULY.2019)'.

\section{Notes:}

${ }^{1}$ Hard-boiled crime fiction refers to a tough, unsentimental form of American crime fiction characterized by its depiction of graphic sex and violence, urban landscapes, and fast paced, colloquial dialogues. Some of the main proponents of the genre include Dashiell Hammett, Raymond Chandler, George Harmon Coxe, and W.R.Burnett.

${ }^{2}$ Chutnification is an expression first used by Salman Rushdie. Chutney refers to an Indian form of sauce or a dry base for a sauce, and chutnification stands for the process of becoming chutney. The expression aptly describes Rushdie's use of language in his works, and later the same trend became common among many Indian writers of English.

3 'Wallah' or 'waala' is the equivalent of 'man' in 'milkman'. The word is usually combined with a noun to create the meaning of 'seller'.

4 'Sahib' is the Hindi equivalent of 'sir' or 'master'. The native inhabitants of colonial India used the term while addressing or conversing with Europeans holding significant social status.

5 'Gullee' is a Hindi word that refers to 'an alley'.

${ }^{6}$ 'Lathi' refers to a long iron bound stick used as a weapon, especially by police officers and security guards.

7 'Aschee' is a Bengali word which means 'coming'.

\section{References:}

Alonso-Breto, I. (2016). The Case of the POCRIF Research Group. Coolabah, 20, 1-8. https://doi.org/10.1344/c02016201-8

Chakraborty, S. (2019, November 15). Interview: Abir Mukherjee, Author of the Wyndham E Banerjee Series. Hindustan Times. https://www.hindustantimes.com/books/interview-abir-mukherjee-author-ofthe-wyndham-banerjee-series/story-mxZI46EE7NjWbDNTgaWXıM.html

Christian, E. (2001). The Postcolonial Detective (Crime Files) (2001st ed.). Palgrave Macmillan.

Christian, E. (2010). Ethnic Postcolonial Crime and Detection (Anglophone). In C. Rzepka \& L. Horsley (Eds.), A Companion to Crime Fiction (pp. 283-295). Wiley-Blackwell.

Fanon, F. (1965). The Wretched of the Earth. Grove Press Inc.

Gamal, A. (2011). Rewriting Strategies in Tariq Ali's Postcolonial Metafiction. Postcolonial Text, 1-19. https://www.postcolonial.org/index.php/pct/article/view/1243/1266 
Gunde, R. (1994, February 2). Decolonization: A Postcolonial Perspective. UCLA Asia Pacific Center. https://www.international.ucla.edu/asia/article/7158

Huang, Y. (2010). Charlie Chan: The Untold Story of the Honorable Detective and His Rendezvous with American History. W.W.Norton.

Humann, H. D. (2020). Hybridisation. In J. Allan, J. Gulddal, S. King, \& A. Pepper (Eds.), The Routledge Companion to Crime Fiction (pp. 57-64). Routledge.

Majumdar, A. (2018, July 8). The Truth has Two Sides: Abir Mukherjee on 'A Rising Man' and 'Smoke and Ashes'. The Indian Express. https://indianexpress.com/article/express-sunday-eye/the-truth-hastwo-sides-abir-mukherjee-on-a-rising-man-and-smoke-and-ashes-5249886/

Makhijani, P. (2017, February 1). The Asian Detective Novel: From Racist Caricature to Authentic Representation. CrimeReads. https://crimereads.com/the-asian-detective-novel-from-racistcaricature-to-authentic-representation/

Morgan, H. J. (2020). Kishwar Desai's Simran Singh Series: Crime, Detection, and Gender. The Journal of Commonwealth Literature, 1-16. https://doi.org/10.1177/0021989420912294

Mukherjee, A. (2016). A Rising Man. Harvill Secker.

Naidu, S. (2020). Race and Ethnicity. In J. Allan, J. Gulddal, S. King, \& A. Pepper (Eds.), The Routledge Companion to Crime Fiction (pp. 111-119). Routledge.

---. (2018). Teaching Postcolonial Crime Fiction. In C. Beyer (Ed.), Teaching Crime Fiction (pp. 83-98). Palgrave Macmillan.

Plato, \& Bloom, A. (1968). The Republic. Basic Books.

Reddy, M. T. (2003). Traces, Codes, and Clues: Reading Race in Crime Fiction. Rutgers University Press.

Roy, S. (2020). Coloniality and Decoloniality. In J. Allan, J. Gulddal, S. King, \& A. Pepper (Eds.), The Routledge Companion to Crime Fiction (pp. 120-128). Routledge.

Rzepka, C. J., \& Horsley, L. (2010). A Companion to Crime Fiction. Wiley-Blackwell.

Schröttner, B. T. (2009). The Value of Post-colonial Literature for Education Processes: Salman Rushdie's Midnight's Children. European Educational Research Journal, 8(2), 285-298.

https://doi.org/10.2304/eerj.2009.8.2.285

Sharma, D. K., Jha, P., \& Kumar, N. (2015). The Politics of Language: Decolonization of Indian English. MIT International Journal of English Language \& Literature, 2(1), 11-16. http://www.mitpublications.org/yellow_images/1428577305_logo_Book-Eng\%2oLiteratureFinal_2.pdf

Singh, P. K. (2013). The Narrative Strands of the Indian English Novel: Needs, Desires, and Directions. In P. K. Singh (Ed.), The Indian English Novel of the New Millennium (pp. 1-28). Cambridge Scholars.

Thiong'o, N. (1986). Decolonising the Mind: The Politics of Language in African Literature. James Currey Ltd. 